\title{
Men and Women Repeatedly Infected With Chlamydia trachomatis Have a Lower Urogenital Bacterial Load
}

Citation for published version (APA):

Wijers, J. N. A. P., van Liere, G. A. F. S., Dukers-Muijrers, N. H. T. M., Wolffs, P. F. G., \& Hoebe, C. J. P. A. (2020). Men and Women Repeatedly Infected With Chlamydia trachomatis Have a Lower Urogenital Bacterial Load. Sexually Transmitted Diseases, 47(11), E51-E53.

https://doi.org/10.1097/OLQ.0000000000001219

Document status and date:

Published: 01/11/2020

DOI:

10.1097/OLQ.0000000000001219

Document Version:

Publisher's PDF, also known as Version of record

Document license:

Taverne

Please check the document version of this publication:

- A submitted manuscript is the version of the article upon submission and before peer-review. There can be important differences between the submitted version and the official published version of record.

People interested in the research are advised to contact the author for the final version of the publication, or visit the DOI to the publisher's website.

- The final author version and the galley proof are versions of the publication after peer review.

- The final published version features the final layout of the paper including the volume, issue and page numbers.

Link to publication

\footnotetext{
General rights rights.

- You may freely distribute the URL identifying the publication in the public portal. please follow below link for the End User Agreement:

www.umlib.nl/taverne-license

Take down policy

If you believe that this document breaches copyright please contact us at:

repository@maastrichtuniversity.nl

providing details and we will investigate your claim.
}

Copyright and moral rights for the publications made accessible in the public portal are retained by the authors and/or other copyright owners and it is a condition of accessing publications that users recognise and abide by the legal requirements associated with these

- Users may download and print one copy of any publication from the public portal for the purpose of private study or research.

- You may not further distribute the material or use it for any profit-making activity or commercial gain

If the publication is distributed under the terms of Article $25 \mathrm{fa}$ of the Dutch Copyright Act, indicated by the "Taverne" license above, 


\title{
Men and Women Repeatedly Infected With Chlamydia trachomatis Have a Lower Urogenital Bacterial Load
}

\author{
Juliën N.A.P. Wijers, MSc, *†t Geneviève A.F.S. van Liere, PhD, *†ł \\ Nicole H.T.M. Dukers-Muijrers, PhD, *†t \\ Petra F.G. Wolffs, PhD, † and Christian J.P.A. Hoebe, MD, PhD*广f
}

\begin{abstract}
We assessed whether patients repeatedly infected with Chlamydia trachomatis (CT) have a lower urogenital or anorectal CT load. A CT-positive retest was independently associated with higher vaginal and higher urine $\mathrm{Cq}$ values $(P<0.01)$. Partial immunity could play a role in repeat urogenital infections, potentially not in anorectal infections.
\end{abstract}

$\mathrm{R}_{\mathrm{e}}^{\mathrm{e}}$ epeat Chlamydia trachomatis (CT) infections remain a challenge in CT control. Repeat CT infections can be caused by reinfections from an untreated sexual partner, new infection from the regular or new partner, or a persistent infection due to treatment failure. Repeat CT infections are common; up to $32 \%$ of patients with CT infection test positive again within 1 year of diagnosis. ${ }^{1,2}$ Repeat infections increase the risk of developing serious reproductive sequelae. ${ }^{3}$ Therefore, retesting CT-positive patients within 3 to 12 months after initial test is an effective control strategy and can be used to enhance the population-based prevention of $\mathrm{CT}^{4} \mathrm{Al}$ though retesting is advised in international guidelines, retesting rates remain typically low $(15 \%-40 \%){ }^{4}$

A high CT bacterial load (hereafter, CT load), frequently expressed as the number of CT bacteria/mL, could potentially affect transmission and occurrence of sequelae. ${ }^{5}$ Some studies suggest that repeat CT infections are associated with a lower CT load potentially due to partial immunity against $\mathrm{CT} .{ }^{6,7}$ Nevertheless, these studies on CT load and repeat infections had some limitations like including only small numbers of patients, presenting only univariable analyses, or only assessing the urogenital site of women. ${ }^{6,7}$ Furthermore, data on repeat anorectal infections are lacking, although these infections are common among both men and women who have sex with men (MSM). ${ }^{8}$ Therefore, we

From the Departments of * Social Medicine and $\dagger$ Department of Medical Microbiology, Care and Public Health Research Institute (CAPHRI), Maastricht University Medical Center (MUMC+), AZ Maastricht; and $\ddagger$ Department of Sexual Health, Infectious Diseases and Environmental Health, South Limburg Public Health Service, AA Heerlen, the Netherlands

Acknowledgments: The authors thank the Medical Microbiology Laboratory of Maastricht University Medical Center for providing the laboratory data, particularly Brian van der Veer (Medical Microbiology Laboratory of Maastricht University Medical Center), for providing the Chlamydia trachomatis cycle quantification data.

Conflict of Interest and Sources of Funding: No interests of conflict exist for all authors. This study received no specific grant from any funding agency in the public, commercial, or not-for-profit sectors.

Correspondence: Juliën N.A.P. Wijers, MSc, Department of Sexual Health, Infectious Diseases and Environmental Health, South Limburg Public Health service, PO Box 2022, 6400 AA, Heerlen, the Netherlands. E-mail: julien.wijers@ggdzl.nl.

Received for publication April 20, 2020, and accepted May 31, 2020.

DOI: 10.1097/OLQ.0000000000001219

Copyright (C) 2020 American Sexually Transmitted Diseases Association. All rights reserved. studied CT load in a relatively large number of both repeat positive urogenital and anorectal samples from men and women.

\section{MATERIALS AND METHODS}

\section{Study Population}

Data from 6170 CT-positive patients (aged $\geq 16$ years) with 7224 CT-positive consultations from January 2012 to June 2018 were used to derive our study population of repeat positives in both men and women from urogenital and anorectal samples. These data originated from the laboratory registry of the Medical Microbiology Laboratory of Maastricht University Medical Center from a total of 62,306 CT tests with a CT positivity of $11.6 \%{ }^{9}$

All samples were tested for CT with the same nucleic acid amplification test (NAAT) for both plasmid and chromosomal DNA (COBAS 4800; Roche Diagnostics, Basel, Switzerland), as per the manufacturer's protocol. ${ }^{10}$ We used the NAAT-derived Cq value as a proxy for CT load. ${ }^{9}$

For women, CT-positive vaginal swabs and CT-positive anorectal swabs were included. For men, CT-positive first void urine samples and CT-positive anorectal swabs were included. The first positive CT test of a patient was defined as the "initial positive test." Only patients with at least one CT-positive retest were included in the study population. Samples that tested positive for CT within 30 days of a previous positive CT sample were excluded to rule out positivity because of possible false-positive results of nonviable recurrent CT $(n=230$ vaginal swabs, $n=76$ urine samples, and $n=66$ anorectal swabs). All positive samples taken later than 30 days after the initial positive test were considered as a "positive retest" in the entire study period.

In total, $n=429$ patients with at least one urogenital or anorectal CT-positive retest were included. Of this sample, $51.5 \%$ were men, the mean age was 28 years, and most had a Western ethnicity $(77.2 \%)$. Furthermore, $88.1 \%$ were diagnosed at the sexually transmitted infection clinic, $9.3 \%$ by the general practitioner, and $2.6 \%$ by hospital medical specialists. Of the patients diagnosed at the sexually transmitted infection clinic, $26.4 \%$ were heterosexual men, $26.6 \%$ were MSM, and $47.0 \%$ were women.

Of the 137 men with at least 1 positive urogenital CT retest, 127 had 1 positive urine retest, and 10 had 2 positive retests (total: $\mathrm{n}=147$ ). Of the 84 men with at least 1 positive anorectal CT retest, 63 had 1 positive retest, 16 had 2 positive retests, and 5 had 3 positive retests (total: $\mathrm{n}=110$ ).

Of the 187 women with at least 1 positive vaginal CT retest, 170 had 1 positive retest, 16 women had 2 positive retests, and 1 woman had 3 positive retests (total: $\mathrm{n}=205$ ). Of the 21 women with at least 1 positive anorectal CT retest, 19 had 1 positive retest, 1 had 2 positive retests, and 1 woman had 3 positive retests (total: $\mathrm{n}=24)$. 


\section{Cycle Quantification Validation for CT Load}

We compared the $\mathrm{Cq}$ values obtained from the diagnostic NAAT with previously determined quantitative in-house polymerase chain reaction, to ensure that the $\mathrm{Cq}$ value can indeed be used as a proxy for CT load in the different sample types. ${ }^{10-12}$ In brief, we quantified CT load by an in-house TaqMan real-time polymerase chain reaction to quantify CT OmpA-gene copies $/ \mathrm{mL} .{ }^{10}$ A full description of the CT load quantification has been described elsewhere. ${ }^{10}$ In an earlier publication, we described the correlations between $\mathrm{Cq}$ values and CT load per sample type in detail. ${ }^{9}$ Overall, high correlations were observed (Pearson $r=>0.88$ ), except for urine samples (Pearson $r=0.61){ }^{9}$

\section{Statistical Analyses}

The main determinant tested was positive retest (binary), in which the initial positive test was used as the reference group and any subsequent positive CT test as the group of interest per sample type. In the main analyses, the association between positive retest and the outcome measure "Cq values," as a proxy for CT load, was assessed using generalized linear models for repeated measures per sample type (vaginal swab, urine sample, and anorectal swab). The analyses data set was aggregated on a consultation level. Every subsequent CT-positive consultation of the same individual, later than at least 30 days of a previous consultation, was counted as a positive retest when the same sample type as at the initial consultation was taken. We adjusted for sex, age (continuous), year of consultation (continuous), number of days between subsequent $\mathrm{CT}$ infection (continuous), concurrent anorectal $\mathrm{CT}$, concurrent oropharyngeal $\mathrm{CT}$, coinfection with urogenital NG, coinfection with anorectal NG, coinfection with oropharyngeal NG, and coinfection with HIV. Only multivariable results are presented. A $P$ value of $<0.05$ was considered statistically significant. Mean values, SDs, (adjusted) mean differences, and 95\% confidence intervals (CI) were calculated.

All analyses were performed using SPSS Version 24 (IBM SPSS Statistics for Windows; IBM Corporation, Armonk, NY).

\section{Medical Ethical Clearance}

The Medical Ethics Committee of the Maastricht University Medical Center (Maastricht, the Netherlands) approved this study (METC 2017-0251) and waived the need for individual written patient consent. Because the retrospective data originated from regular care and were analyzed anonymously, no further informed consent for data analysis was obtained.

\section{RESULTS}

\section{Men}

In multivariable analyses, a positive urine retest $(n=147)$ was associated with higher $\mathrm{Cq}$ values (mean difference, $1.08 \mathrm{Cq}$; $95 \%$ CI, $0.27-1.90 ; P=0.009)$ compared with the initial positive urine test $(\mathrm{n}=137$; Fig. 1$)$. In a sensitivity analyses, by including only the first positive urine retest, results were similar (mean difference, $1.00 \mathrm{Cq} ; 95 \% \mathrm{CI}, 0.17-1.82 ; P=0.02$ ).

In multivariable analyses, a positive anorectal retest ( $\mathrm{n}=110$ ) was not associated with $\mathrm{Cq}$ values (mean difference, $0.10 \mathrm{Cq} ; 95 \% \mathrm{CI},-1.15$ to $1.35 ; P=0.88$; Fig. 1 ). In a sensitivity analyses, by including only the first positive anorectal retest, results were similar and not statistically significant.

\section{Women}

In multivariable analyses, a CT-positive vaginal retest $(n=205)$ was associated with higher vaginal $\mathrm{Cq}$ values compared with the initial positive vaginal test $(n=187$; mean difference, 1.51
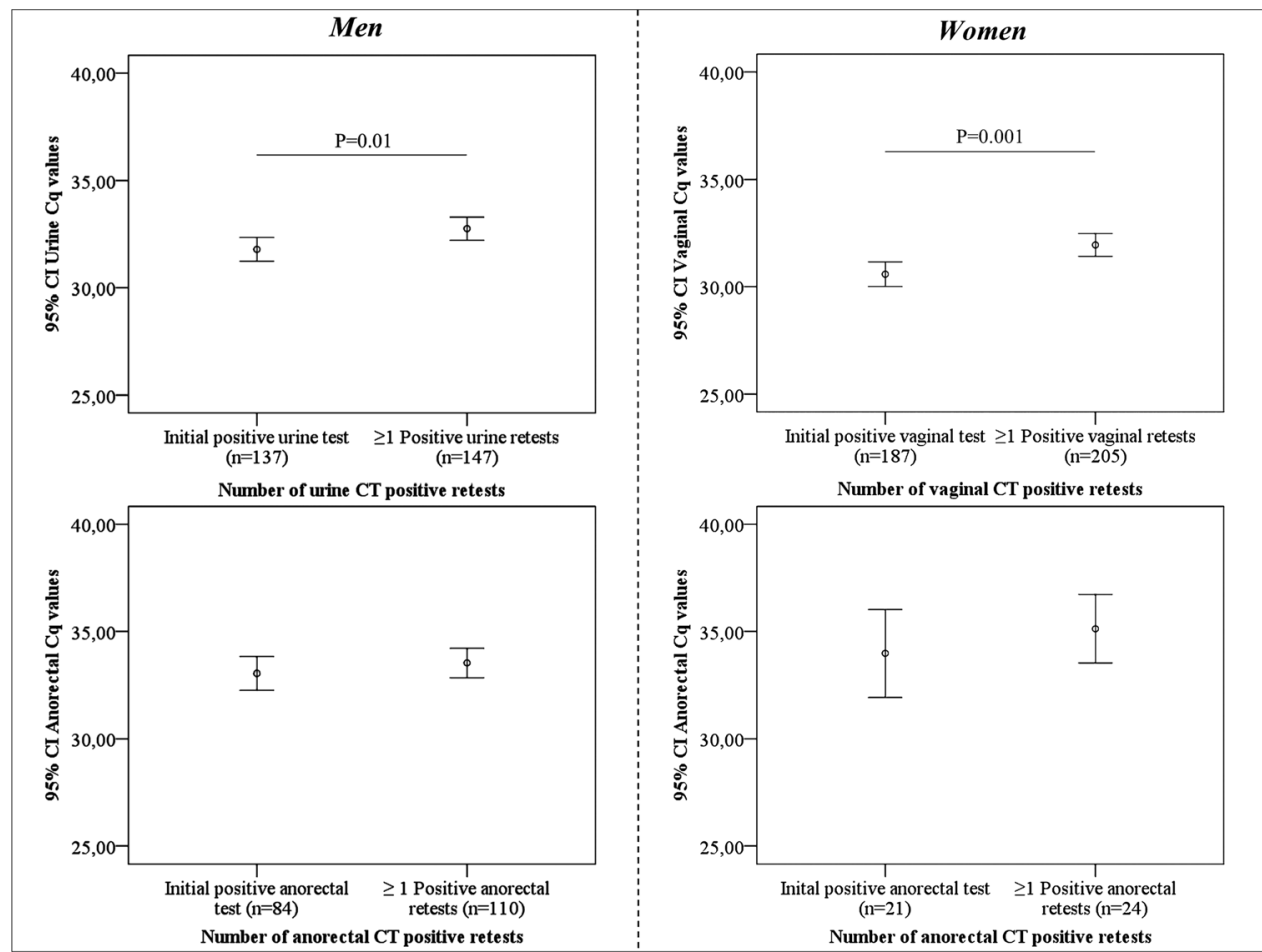

Figure 1. Errors bars with $95 \%$ Cls showing the CT bacterial load, estimated by Cq values, of the initial positive test and $\geq 1$ repeat infections of the urogenital and anorectal site of men and women. 
Cq; 95\% CI, 0.58-2.44; $P=0.002$ ) (Fig. 1). In a sensitivity analyses, by including only the first positive vaginal retest, results were similar (mean difference, $1.36 \mathrm{Cq} ; 95 \%$ CI, 0.42-2.30; $P=0.004$ ).

In multivariable analyses, a CT-positive anorectal retest $(\mathrm{n}=24)$ was not associated with $\mathrm{Cq}$ values in women (mean difference, $1.00 \mathrm{Cq}$; $95 \% \mathrm{CI},-1.87$ to $3.87 ; P=0.49$; Fig. 1 ). In a sensitivity analyses, by including only the first positive anorectal retest, results were similar and not statistically significant.

\section{DISCUSSION}

This is the largest study to date assessing the CT bacterial load, estimated by Cq values, of repeat CT infections per sample type adjusted for potential confounders. Men and women repeatedly infected with CT have higher urogenital Cq values and likely a lower CT load. However, this was not true for anorectal samples, as no difference was observed in Cq values in anorectal samples of both men and women.

A strength of our study is the relatively large number of repeat infections analyzed stratified per sample type. Our multivariable analyses confirm the univariable findings of smaller studies indicating that women repeatedly infected with CT have a lower urogenital CT load. ${ }^{6,7}$ To our knowledge, this is the first study showing that also men repeatedly infected with CT have a lower urogenital CT load.

A limitation was that the $\mathrm{Cq}$ values of urine samples of men were moderately correlated with the CT load of urine samples of men (Pearson $r=0.61$ ). Therefore, the results of urine $\mathrm{Cq}$ values could be a less stable indication of CT load. This is an expected finding, as we know, concentration in urine can differ interindividually and intraindividually and with time because infected cells from the male urethra may get washed out by first void urine.

We showed that men and women repeatedly infected with CT have a lower urogenital CT load, which was also observed in earlier studies, but only among women. ${ }^{6,7}$ Both studies suggest that partial immunity against CT could play a role. However, further research is needed including longitudinal data, immunological markers, and duration of the CT infection for more evidence. Furthermore, patients with a lower CT load could have a lower impact on transmission of CT. It is likely that patients with initial CT infections may have a higher impact on ongoing transmission than patients repeatedly infected with CT. This could highlight the importance of targeting control measures, such as retesting, to those patients with an initial CT infection.

Repeat anorectal CT infections of women were not associated with a lower CT load, which could be a result of the relatively low number of anorectal repeat infections diagnosed among women $(n=24)$. Among men, however, a substantial number of repeat anorectal infections were diagnosed $(n=110)$, and there was also no association between CT load and repeat infection. If the number of repeat anorectal CT infections in women were larger, we would expect a similar anorectal load of repeat infections as men, because men and women have an equal extragenital load. ${ }^{9}$ Nevertheless, because anorectal infections are common among MSM and women, testing and retesting the anorectal site remain important to enhance CT control. Potentially the partial immunity theory does not hold for anorectal infections, which could be related to treatment (azithromycin vs. doxycycline). Because the treatment effectiveness of doxycycline is higher than azithromycin in uncomplicated anorectal infections, ${ }^{13}$ it could potentially affect the immune response of the body. However, this is only speculative and further research is needed to assess this pattern.

An earlier study assessed the CT load of repeat infections among African American women and showed a lower urogenital CT load when repeatedly infected with CT (5.6 vs. $4.5 \mathrm{CT} / \mathrm{mL}$; $P=0.015){ }^{6}$ The authors suggest that the generalizability of the results could be a problem for other populations. However, our results among mainly Western individuals are comparable to this particular study.

In conclusion, men and women repeatedly infected with CT have a lower urogenital bacterial load potentially because of partial immunity against CT. However, repeat anorectal infections of men and women were not associated with a lower CT load, indicating that repeat anorectal infections have a similar impact on transmission and sequalae to that of initial anorectal infections.

\section{REFERENCES}

1. Hosenfeld CB, Workowski KA, Berman S, et al. Repeat infection with chlamydia and gonorrhea among females: A systematic review of the literature. Sex Transm Dis 2009; 36:478-489.

2. Fung M, Scott KC, Kent CK, et al. Chlamydial and gonococcal reinfection among men: A systematic review of data to evaluate the need for retesting. Sex Transm Infect 2007; 83:304-309.

3. den Heijer CDJ, Hoebe CJPA, Driessen JHM, et al. Chlamydia trachomatis and the risk of pelvic inflammatory disease, ectopic pregnancy, and female infertility: A retrospective cohort study among primary care patients. Clin Infect Dis 2019; 69:1517-1525.

4. Workowski KA. Centers for Disease Control and Prevention sexually transmitted diseases treatment guidelines. Clin Infect Dis 2015; 61 (Suppl 8):S759-S762.

5. Vodstrcil LA, McIver R, Huston WM, et al. The epidemiology of Chlamydia trachomatis organism load during genital infection: A systematic review. J Infect Dis 2015; 211:1628-1645.

6. Gupta K, Bakshi RK, Van Der Pol B, et al. Repeated Chlamydia trachomatis infections are associated with lower bacterial loads. Epidemiol Infect 2018; 1-3.

7. Walker J, Tabrizi SN, Fairley CK, et al. Chlamydia trachomatis incidence and re-infection among young women - behavioural and microbiological characteristics. PLoS One 2012; 7:e37778.

8. Chan PA, Robinette A, Montgomery M, et al. Extragenital infections caused by Chlamydia trachomatis and Neisseria gonorrhoeae: A review of the literature. Infect Dis Obstet Gynecol 2016; 2016:5758387.

9. Wijers JNAP, Dukers-Muijrers NHTM, van Liere GAFS, et al. Men and women have an equal oropharyngeal and anorectal Chlamydia trachomatis bacterial load: A comparison of three anatomic sites. J Infect Dis 2019; jiz668.

10. Dirks JA, Wolffs PF, Dukers-Muijrers NH, et al. Chlamydia trachomatis load in population-based screening and STI-clinics: Implications for screening policy. PLoS One 2015; 10:e0121433.

11. van Liere GA, Dirks JA, Hoebe CJ, et al. Anorectal Chlamydia trachomatis load is similar in men who have sex with men and women reporting anal sex. PLoS One 2015; 10:e0134991.

12. Dirks JA, van Liere GA, Bogers S, et al. Natural course of Chlamydia trachomatis bacterial load in the time interval between screening and treatment in anogenital samples. PLoS One 2015; 10:e0145693.

13. Dukers-Muijrers NHTM, Wolffs PFG, De Vries H, et al. Treatment ef fectiveness of azithromycin and doxycycline in uncomplicated rectal and vaginal Chlamydia trachomatis infections in women: A multicenter observational study (FemCure). Clin Infect Dis 2019; 69:1946-1954. 